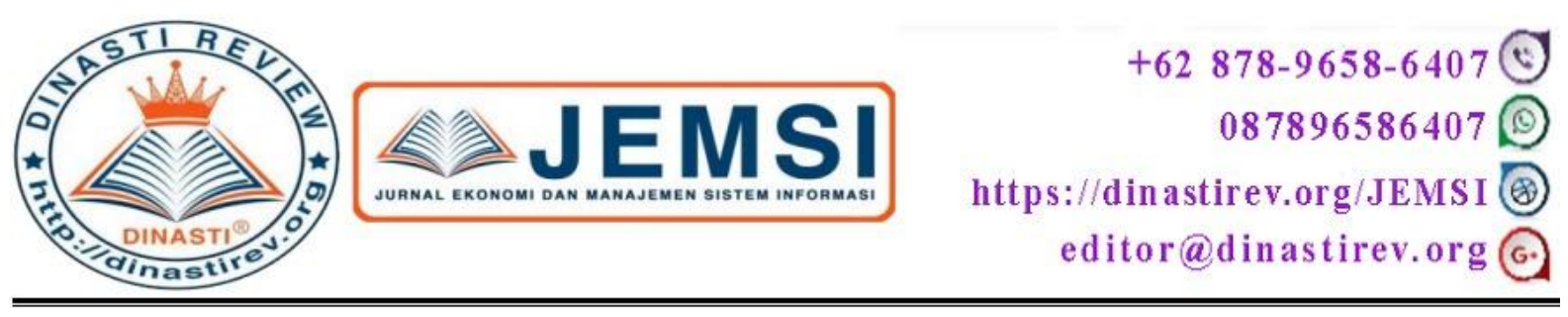

\title{
SISTEM INFORMASI DAN PEMESANAN PENJUALAN PALLET KAYU MENDASARKAN WEB PADA PT. RKA PURWAKARTA
}

\author{
Ahmad Apandi \\ Universitas Mercu Buana, Jakarta
}

\begin{tabular}{|c|l|}
\hline ARTICLE INFORMATION & Abstrak: PT. Perusahaan Rizki Kartika Ariana \\
Received: 01 September 2019 & $\begin{array}{l}\text { Purwakarta adalah perusahaan yang bergerak dalam } \\
\text { Revised: 11 September 2019 } \\
\text { menjual palet kayu dalam melakukan pemasaran dan } \\
\text { Issued: 21 September 2019 penjualan menggunakan cara manual. Ini } \\
\text { berarti dari orang ke orang atau dari satu perusahaan } \\
\text { ke perusahaan lain. Pada awalnya, perusahaan ini } \\
\text { hanya memproduksi produk yang akan dijual ke } \\
\text { daerah lokal atau hanya di Purwakarta. Untuk } \\
\text { memperbesar dalam menjual produk, penulis mencoba } \\
\text { ahmadapandi933@gmail.com } \\
\text { untuk membuat pada aplikasi jual line atau berbasis } \\
\text { web. Melalui aplikasi ini, pelanggan dapat membeli } \\
\text { produk whithour menjual penjual wajah dengan wajah } \\
\text { transaksi whichis dilakukan dengan menggunakan } \\
\text { website harus memberikan kemudahan kepada banyak } \\
\text { orang dan pelanggan dalam memiliki akses untuk } \\
\text { melakukan hal ini, menggunakan pemrograman } \\
\text { MySQL bahasa dan PHP (Hipertext bahasa } \\
\text { pemrograman web). } \\
\text { Kata Kunci: Menjual aplikasi di web berbasis, } \\
\text { MySQL, PHP }\end{array}$ \\
\end{tabular}

\section{PENDAHULUAN}

Web adalah halaman di internet yang berisi sumber informasi yang terkandung pengetahuan ini bermanfaat bagi readers.As nya perkembangan teknologi yang semangkin cangggih, web di telah diambil sebagai fasilitas dalam melakukan proses penjualan seperti menunjukkan barang gambar-gambar yang dipasarkan di web di bunga tersebut yang buyer. maka bahwa penggunaan web sekarang kecuali mengandung sumber informasi juga dapat membuat itu sebagai sistem informasi penjualan media.

Masalah muncul ketika banyak pesaing yang juga dilakukan bisnis yang sama, fakta mengakibatkan pasang surut di penjualan di pt.Rizki kartika purwakarta ariana this.Some dari mereka ketika masalah untuk kualitas bahan baku dibuat tidak spesifik baku dijual, sizing bahan baku, semacam baku dalam kebasahan produksi atau kekeringan, cara pemasaran, harga etc.A mentah kemungkinan bahwa kurangnya pembeli. 
Dari jumlah tersebut pt.Rizki kartika purwakarta ariana sebagai penjual kayu palet di purwkarta untuk memanfaatkan kemajuan teknologi informasi dalam pemasaran yang ditawarkan oleh kayu pallet internet diperdagangkan di it.Over internet, pengguna tidak hanya menikmati informasi tentang bahan baku itu, kayu lapis namun dapat mengakses informasi lebih lanjut yang therein.For contoh setiap klien ingin membeli, bebas memilih ukuran bahan baku, semacam baku dalam produksi.

Dan ketika pelanggan memilih barang yang dipilih pelanggan berikutnya cukup termasuk daftar bahan baku, maka proses pelanggan transaksi membayar pembayaran transfer account.After Bank semua transaksi pembayaran dilakukan kemudian, perusahaan akan menerima laporan bahwa pelanggan memesan bahan baku telah Selesaikan proses pembayaran, selanjutnya perusahaan akan mengirimkan bahan baku dibuat memerintahkan kepada customers.In kata lain, fasilitas yang disediakan oleh kemudahan website, diharapkan untuk menyediakan fasilitas untuk pembeli dalam mendapatkan informasi dan transaksi pemesanan bahan baku secara efisien, dan membuat proses pembayaran dan menghemat waktu.

Dari masalah pada penulis bersedia membantu perusahaan untuk menginformasikan yang lebih luas maka penulis untuk menuangkan dalam objek penelitian berjudul ini sistem informasi penjualan dan pemesanan halaman pt web didasarkan pada kayu palet PT.Rizki Kartika Ariana Purwakarta.

\section{KAJIAN PUSTAKA}

\section{Analisis dan khususnya dalam desain}

Sistem menurut rosa dan m.shalahuddin $(2011 ; 16)$, analisis sistem adalah kegiatan untuk melihat sistem yang sudah beroperasi, lihat bagian mana yang berkualitas baik dan tidak berkualitas baik, dan kemudian ke dokumen kebutuhan untuk dipekerjakan di desa melawan klan dari orang-orang kafir di semua sistem baru .Systems analisis telah membutuhkan kesabaran teguh studi dari sistem yang ada dan solusi yang di mengusulkan alokasi anggaran tambahan untuk sebagian besar Anda sedikit lebih dari selama fase persiapan berbagai survei menunjukkan tanda-tanda atau investigasi dari sistem .suatu sumber daya sudah termasuk software dan hardware.

Menurut Fatta (2007; 44), desain sistem adalah pemecahan masalah teknik (dengan analisis sistem pelengkap) yang dirangkai kembali Bagian komponen ini menjadi sistem yang Lengkap-harapannya, sistem yang diperbaiki.

\section{Sistem Informasi}

Menurut O'brain Dan Marakas (Indra, Dedy 2011; 4), "Sebuah Sistem Informasi (IS) dapat berupa kombinasi terorganisir dari orang, hardware, software, komunikasi, jaringan, sumber daya data, dan kebijakan dan prosedur yang menyimpan, Memperoleh kembali , mengubah, dan menyebarkan informasi dalam sebuah organisasi”.

Sebuah sistem informasi dapat diselenggarakan, kombinasi perangkat keras, perangkat lunak, jaringan komunikasi, sumber daya data, dan kebijakan dan prosedur tetap, mengambil, mengubah, dan menyebarkan informasi dalam sebuah organisasi. Sistem informasi adalah suatu sistem yang menyediakan informasi bagi manajemen dalam pengambilan keputusan dan operasi perusahaan, di mana sistem itu kombinasi masyarakat, teknologi informasi dan prosedur prosedur terorganisir.

Ini adalah sistem informasi nya benar ada sebelum penciptaan diciptakan, teknologi tetapi dengan sistem informasi yang memberikan langkah-langkah cepat, komputer berbasis 
tepat dan akurat dalam pengolahan dan proses data, tidak hanya dirasakan oleh manajemen puncak tapi semua yang terlibat dalam perusahaan memiliki mudah dan betapa menakjubkan sistem informasi berbasis komputer ini yang merupakan revolusi dari sistem manajemen informasi pertama kali digunakan.

Pengembangan sistem manfaat pengembangan sistem informasi dapat berarti suatu sistem baru untuk menggantikan sistem yang lama secara keseluruhan atau memperbaiki sistem yang ada. Manfaat sitem informasi dalam pengendalian intern adalah sebagai berikut

1) Sitem manajemen informasi untuk keputusan mendukung sistem informasi suastu dimana keputusan itu dibuat dapat tertutyp atau sistem open.A bahwa keputusan keputusan split tertutup meganggap dari masukan yang tidak diketahui dalam sistem ini dari pengambilan keputusan dianggap tahu perangkat alternatif dan semua karena atau hasil dari masingmasing

2) Sistem informasi untuk mengontrol manajemen adalah sistem dimana informasi tentang pengelolaan penendalian diperlukan oleh manajer departemen untuk mengukur pekerjaan, memutuskan tindakan pengendalian, merumuskan aturan personil keputusan baru untuk diterapkan operasional dan mengalokasikan sumber daya.

3) Sistem informasi untuk mengontrol operasional adalah proses lebih lanjut bahwa kegiatan operasional akan diadakan di kontrol .Operational yang efektif dan efisien dengan menggunakan prosedur dan aturan keputusan yang telah ditentukan keputusan .Sebagian pertama dapat diprogram.

4) Sistem informasi manajemen oleh organisasi fungsi adalah sistem manajemen informasi dapat diaanggap sebagai suatsufederasi dari berdasarkan fungsi yang diadakan di sebuah organisasi aplikasi membuthkan .Setiap subsistem ke membentuksemua proses informasi yang berkaitan dengan fungsinya, walaupun akan terkait dengan basis date. Sebuah model piring dan beberapa program komputer yang biasa untuk setiap sub sistem fungsional. Dalam masing-masing modal dalam jumlah besar sistem contoh fungsional sudah ada dari aplikasi ini cukup masuk akal untuk proses transaksi yang berlangsung, pada kontrol dari biaya operasional, pengendalianmanajemen dan perencanaan strategis bank sentral.

5) sistem informasi untuk perencanaan strategis bank sentral adalah sistem informasi yang terintegrasi untuk itu yang bertujuan untuk strategis mengembangkan kegiatan mereka dalam pembiayaan oleh organisasi yang akan mampu mencapai nya adalah mencapai tujuan. Horison waktu untuk perencanaan strategis bank sentral cenderung untuk waktu yang lama Jadi bahwa perubahan mendasar telah dibuat dalam organisasi pusat dapat diselenggarakan di penutupan.

\section{Penjualan}

Penjualan adalah pendapatan utama perusahaan karena jika penjualan produk dan jasa tidak dikelola dengan baik maka secara langsung. dapat biaya perusahaan ini dapat disebabkan karena target penjualan tidak harus dicapai dan akan berkurang. pendapatan wasAccording untuk joel g.Siegel dan joe k.Shim (Nurcahyono 2009; 67), mendefinisikan penjualan adalah penerimaan yang diperoleh dari pengiriman barang atau jasa memberikan pada jam sebagai barang pertimbangan.

Menurut (Winardi, 2010) mengumpulkan tempat penjualan adalah ketika dua aspek penting yang merupakan penjual dan pembeli yang melakukan kegiatan dengan tujuan menerapkan proses dari barang pertukaran atau jasa memiliki nasihat yang benar akurat sebagai uang.

Menurut (henry simamora, 2009) penjualan dalam penjualan contexts.A yang berbeda 
merupakan kegiatan yang banyak dilakukan (lazim) di sebuah perusahaan dan memaksakan biaya kotor kepada konsumen atau barang penerima atau jasa. derstanding penjualan ini salah satu lead lebih pada sistem perusahaan dan bagaimana kerja perusahaan.

\section{a. Penjualan Akuntansi Sistem Informasi.}

Penjualan Akuntansi Sistem Informasi adalah suatu sistem informasi yang menyelenggarakan serangkaian prosedur dan metode yang dirancang untuk menghasilkan, menganalisa, menyebarkan dan memperoleh informasi untuk mendukung pengambilan keputusan mengenai penjualan. Tujuan dari sistem penjualan adalah: order penjualan Rekam cepat dan akurat, memverifikasi konsumen yang berhak menerima kredit, mengirim produk dan menyediakan layanan tepat waktu, seperti yang dijanjikan kepada konsumen, membuat tagihan atas produk dan jasa secara tepat waktu dan akurat, merekam dan penerimaan kas mengklasifikasikan cepat dan akurat, pasca penjualan dan penerimaan kas ke rekening piutang, untuk menjaga keamanan produk dan untuk menjaga kas perusahaan.

\section{b. Sistem Informasi Kas Penjualan Akuntansi.}

Penjualan tunai adalah penjualan dengan mengambil barang dari supplier dan langsung dikirim ke pelanggan dengan pembayaran langsung menggunakan uang tunai. Sistem penjualan tunai pada umumnya didasarkan pada asumsi bahwa pembeli akan mengambil barang setelah harga barang dibayar ke kasir. Dokumen-dokumen yang digunakan dalam penjualan tunai adalah faktur penjualan tunai (FPT) dan kaset kasir.

\section{c. Penjualan kredit Akuntansi Sistem Informasi}

Penjualan kredit adalah penjualan yang pembayaran tidak diterima sekaligus (tidak dibayar penuh). Pembayaran dapat diterima melalui dua tahap atau lebih, yang dibuat di angsuran. Menurut Mulyadi (2001: 214), dokumen yang digunakan dalam sistem penjualan kredit adalah: Delivery Order dan Salinan, Penjualan Kontrol Tindak lanjut Copy, Crossindeks File Copy, Faktur Penjualan dan Salinan, Rekapitulasi Harga Pokok Penjualan, Memorial Bukti.

\section{d. Sistem Informasi Akuntansi Penerimaan Kas}

Penerimaan kas perusahaan berasal dari dua sumber utama, yaitu penerimaan dari penjualan tunai dan penerimaan kas dari piutang atau dari penjualan secara kredit. sistem penerimaan kas dari penjualan tunai melibatkan beberapa fungsi terkait, yaitu: Penjualan Fungsi, Fungsi kas, Gudang Fungsi, Pengiriman Fungsi, Akuntansi Fungsi.

\section{e. Sistem Pengendalian Intern}

Sistem Pengendalian Intern meliputi struktur organisasi, metode dan pengukuran yang terkoordinasi untuk menjaga kekayaan organisasi, mengecek ketelitian dan keandalan akuntansi, mendorong efisiensi dan mendorong dipatuhinya kebijakan manajemen. Tujuan dari sistem pengendalian internal menurut definisi adalah: Menjaga kekayaan organisasi, mengecek ketelitian dan keandalan data akuntansi, mendorong efisiensi dan mendorong dipatuhinya kebijakan manajemen.

\section{f. Sistem Informasi Berbasis Komputer Akuntansi}

Sebuah sistem informasi akuntansi berbasis komputer adalah sistem informasi yang menggunakan teknologi komputer dalam mengelola data perusahaan atau transaksi ke dalam 
informasi yang tepat, akurat, dan relevan dalam pengambilan keputusan. Ada dua kemungkinan yang bisa terjadi dalam pencatatan data yang akan menentukan langkahlangkah berikutnya atau pengolahan data dalam komputer, yaitu: (1) Data rekaman hampir sama dengan sistem manual, yang bukti transaksi yang digunakan kemudian diolah oleh komputer di sesuai dengan format yang telah diprogram. (2) perekaman data dilakukan langsung ke komputer menggunakan terminal. Dalam organisasi data, pengolahan data berbasis komputer dapat dilakukan melalui dua pendekatan tradisional dan pendekatan database.

\section{Penjualan online}

Apakah melakukan kegiatan penjualan dari mencari calon pembeli untuk menawarkan produk atau barang dengan memanfaatkan jaringan internet yang didukung oleh satu set perangkat elektronik sebagai penghubung dengan jaringan internet. Pertama dimulai pada tahun 1990 Tim Berners Lee menciptakan browser web WorldWideWeb yang mengubah jaringan telekomunikasi akademik ke dalam sistem komunikasi untuk semua orang setiap hari secara global dikenal sebagai Internet.

\section{Prototipe}

Prototipe adalah versi dari sistem potensial yang disediakan untuk pembangunan dan pengguna potensial yang dapat memberikan gambaran bagaimana kira-kira sistem akan berfungsi jika telah diatur dalam bentuk lengkap. Proses produksi prototipe disebut prototyping. tujuannya adalah untuk menghasilkan prototipe secepat mungkin, dan mendapatkan umpan balik secepat mungkin dari pengguna yang akan memungkinkan prototipe ditingkatkan secepat mungkin, di mana proses ini biasanya diulang beberapa kali sehingga menghasilkan prototipe yang dianggap sempurna ( McLeod dan Schell 2007; 157).

Prototipe adalah model kerja dasar pengembangan program (software) atau perangkat lunak. Prototipe dalam bahasa Inggris "prototipe" juga disebut prototipe. Prototipe ini biasanya dibuat sebagai model untuk tujuan demonstrasi atau sebagai bagian dari pengembangan perangkat lunak atau proses manufaktur. Kata prototipe berasal dari bahasa Latin, yaitu kata "proto" yang berarti asli, dan "typus" yang berarti bentuk atau model. Dalam konteks non-teknis, Prototip adalah contoh spesifik sebagai wakil dari kategori tertentu.

Dalam bidang desain, prototipe atau prototipe atau disebut juga pola dasar adalah bentuk awal sebagai contoh atau ukuran standar dari suatu entitas. Sebuah prototipe dibuat sebelum dikembangkan atau tepatnya dibuat untuk pengembangan sebelum dibuat dalam skala sebenarnya atau sebelum diproduksi massal.

Prototipe adalah Kerangka Javascript dibuat untuk lebih memudahkan proses membangun aplikasi berbasis web. Metode sebagai paradigma baru dalam pengembangan sistem informasi Protyping, bukan hanya merupakan evolusi dari metode pengembangan sistem informasi yang ada, tetapi pada saat yang sama adalah revolusi dalam pengembangan sistem informasi manajemen.

Umumnya terkait dengan pandangan pengguna dari sistem, hanya display prototipe bagi pengguna cukup untuk memeriksa apa yang dibutuhkan. Menu, bentuk tampilan input, tampilan output, atau laporan dicetak, pertanyaan, pesan adalah kandidat ideal untuk prototipe.

Di sisi lain, perhitungan yang rumit, pengumpulan data dan update realtime, dan sistem ilmiah sangat sulit untuk model. Sistem yang paling cocok untuk prototyping adalah salah satu dari banyak hal yang bergantung pada sistem input / output pengguna. Sistem dengan 
transaksi on-line dikendalikan melalui menu, layar, formulir, laporan, daftar dan perintah. Keuntungan dari prototyping adalah sebagai berikut:

1) Menghasilkan kondisi yang lebih baik daripada produksi yang dihasilkan oleh metode Tulisan ditulis spesifikasi'.

2) Pengguna dapat mempertimbangkan beberapa perubahan selama prototipe tersebut masih dalam bentuk.

3) Memberikan hasil yang lebih akurat dari perkiraan sebelumnya, karena fungsi yang diinginkan dan kerumitannya sudah dikenal.

4) Pengguna puas. Pertama, pengguna bisa berkenalan melalui komputer. Dengan melakukan prototipe (dengan analisis yang sudah ada), pengguna belajar tentang komputer dan aplikasi yang akan dibuat untuk mereka. Kedua, pengguna terlibat langsung dari awal dan memotivasi semangat untuk mendukung analisis selama proyek

\section{KAJIAN PUSTAKA}

Penelitian oleh Silviana Dwitaruni Lesmana (2013), mengenai sistem informasi Penjualan sepeda motor (Journal of engineering dan ilmu komputer - Volume 2 No 8 Oktober 2013). Menyimpulkan bahwa setelah pelaksanaan aplikasi di perusahaan, tingkat penjualan di segmen pasar yang lebih baik dan dapat dilakukan setiap saat tanpa ruang dan waktu batas. Sistem ini membantu kinerja pegawai dalam memberikan informasi kepada pelanggan, sehingga dapat mempersingkat waktu dan menghemat lebih banyak biaya dalam pemesanan sepeda motor.

Kurniawan (2013), mengenai Sistem Informasi untuk penjualan ponsel (Pro Business Journal - Volume 6 No. 2 - Agustus 2013). Menyimpulkan bahwa untuk membantu memberikan informasi tentang produk terbaru dari Sel Pangandaran toko OK untuk konsumen dan membantu dalam proses pembelian produk secara efektif dan efisien dan mempercepat pengolahan data penjualan.

Penelitian Rochmawati Daud ini (2014), mengenai pengembangan sistem informasi akuntansi untuk penjualan dan penerimaan kas berbasis komputer di perusahaan kecil (Jurnal Ilmu Komputer dan Bisnis Pro-Volume 12 No. 1 Maret 2014). Menyimpulkan bahwa Berdasarkan hasil analisis dan pembahasan dalam bab 4, kesimpulan yang dapat ditarik meliputi:

1) Jumlah karyawan di PT. Kepercayaan Teknologi tidak memadai, menyebabkan duplikat tugas terjadi di setiap bagian.

2) Karyawan yang masih memiliki hubungan keluarga dengan pemilik tidak bekerja dengan baik, mereka hanya menggunakan status mereka untuk keuntungan pribadi.

3) Tidak ada pemisahan yang jelas tugas antara karyawan antar departemen, karyawan gudang dapat mengisi penjualan, atau karyawan penjualan dapat melakukan pekerjaan administratif.

4) Prosedur Penjualan dalam sistem yang sedang berjalan di PT. Kepercayaan Teknologi tampaknya rumit dan benar-benar membuat kesempatan untuk melakukan penipuan semakin terbuka lebar.

5) Bagi perusahaan yang memiliki cukup omset besar setiap bulan, sistem yang masih manual tidak lagi dapat mendukung kegiatan penjualan dan penerimaan kas di PT.Trust Teknologi.

Penelitian Dian Permata Sari (2018), mengenai Merancang Sistem Informasi SDM dengan prestasi di GD global Surya (Journal of Ilmu Komputer-Volume 1 No 1 2018). Menyimpulkan bahwa Berdasarkan hasil analisis dan dapat disimpulkan bahwa:

1) Pada sistem yang sedang berlangsung yang belum menggunakan aplikasi khusus berdasarkan komputerisasi dan basis data, dokumen masih dilakukan secara konvensional, dicatat dan kemudian disimpan oleh petugas tertentu . Jadi kita perlu 
desain untuk membuat sistem yang lebih baik.

2) Tahapan proses yang dilakukan masih dalam bentuk desain sistem dan belum sepenuhnya dilakukan tahapan hingga pelaksanaan program dan perhitungan yang rumit dengan menggunakan metode kualitatif berdasarkan data pengujian dan analisis jumlah matang . Jadi kita perlu tahap keberlanjutan. Desain yang telah dibuat dapat menjadi masukan dan referensi bagi pembangunan yang lebih baik.

3) Dengan membuat sistem berbasis web dan basis data. Desain dari sistem yang telah dibuat memberikan kemudahan dalam pengolahan data HR Berprestasi sehingga penggunaan komputerisasi online, sebagai sarana informasi menjadi lebih maksimal.

4) Dengan 2 metode pemecahan diharapkan pemecahan masalah dapat menjadi lebih spesifikasi menggunakan metode pengembangan kualitatif dengan bahkan data yang lebih akurat.

Penelitian oleh Andini Tirta Cricelia Sulaeman (2017). Tentang analisis sistem informasi akuntansi persediaan pelumas, sebuah studi kasus pada PT. Fajar Indah Kusuma. (General Penelitian Akuntansi Kelangsungan Volume 12 No 1-2017). Menyatakan bahwa PT. Fajar Indah Kusuma belum menerapkan sistem informasi akuntansi persediaan yang cukup, karena ada beberapa kekurangan dalam pembagian fungsi, terutama di gudang mana perusahaan hanya memiliki satu karyawan yang merangkap pekerjaan yang dapat berisiko menyebabkan kesalahan dan pengendalian internal yang masih melakukan perhitungan persediaan oleh semua karyawan disebut gudang, yang berisiko memanipulasi data karena kurangnya pengawasan.

\section{METODE PENELITIAN}

\section{Kerangka Penelitian}

Untuk memperjelas tahapan-tahapan yang akan dilakukan dalam penelitian ini, kerangka penelitian diperlukan yang menjelaskan langkah-langkah yang perlu dilakukan untuk mengatasi kendala yang ada. kerangka penelitian yang digunakan.

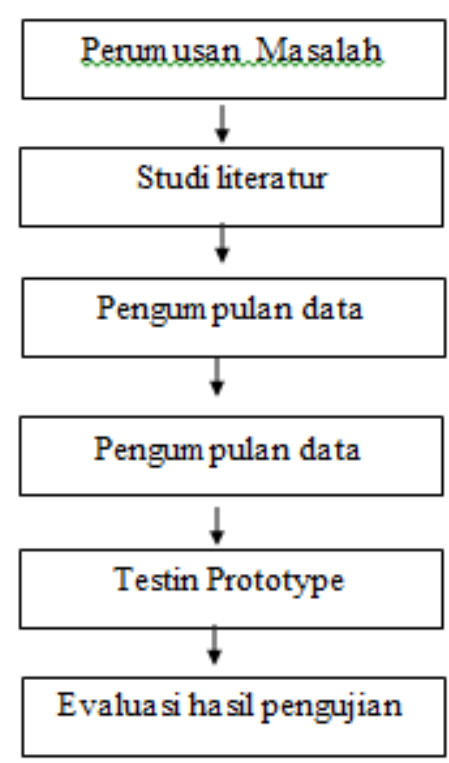

\section{Gambar 1. Kerangka Penelitian}

Berdasarkan kerangka penelitian di atas, masing-masing diskusi tentang tahapan penelitian ini dapat digambarkan sebagai berikut: 
1) Rumusan Masalah, Pada tahap ini penulis merumuskan ruang lingkup masalah yang akan dibahas dalam penelitian ini.

2) Sastra Studi, Pada tahap ini penulis melakukan apa yang disebut kajian literatur yang mempelajari buku-buku referensi, artikel di situs yang relevan tentang penjualan berbasis web.

3) Pengumpulan Data, Pada tahap ini penulis melakukan pengumpulan data, pengumpulan data merupakan tahap penting dalam proses penelitian, di mana penulis harus mendapatkan data yang dibutuhkan dalam merancang sistem.

4) Analisis dan Perencanaan, Pada tahap ini, analisis dan desain sistem informasi sesuai dengan kebutuhan menggunakan model air terjun, sedangkan model air terjun yang digunakan dapat dilihat pada gambar berikut:

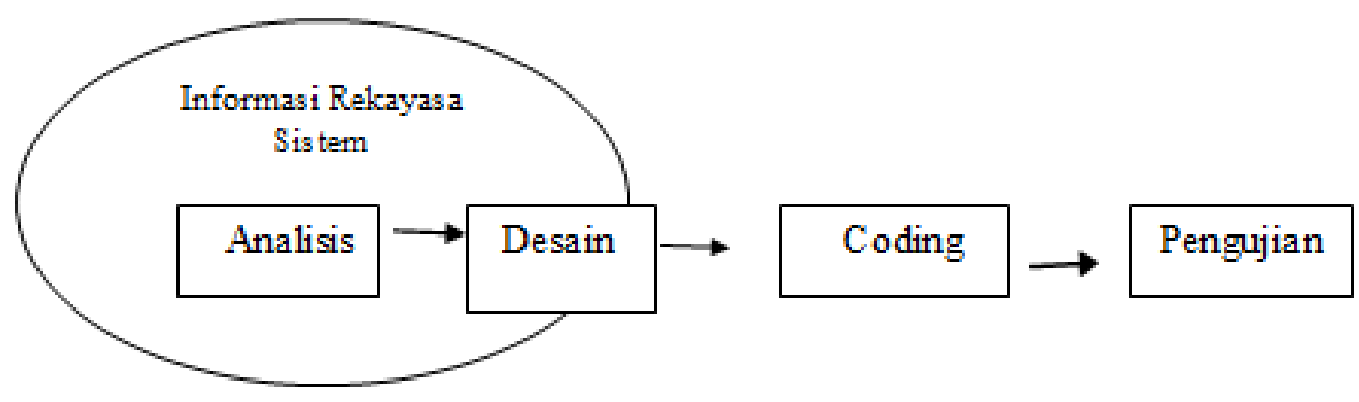

\section{Gambar 2. Model Waterfull}

Berdasarkan model air terjun bahwa ia telah ditarik, pembahasan setiap tahap dalam model dapat digambarkan sebagai berikut:

1) Analisis

Pada tahap ini analisis kebutuhan sistem yang akan dirancang meliputi data yang diperlukan dalam desain sistem.

2) Desain

Pada tahap ini desain aplikasi dilakukan yang bertujuan untuk memberikan gambaran tentang apa aplikasi harus dilakukan dan bagaimana tampilannya.

3) Coding

Pada tahap ini desain harus diterjemahkan ke dalam sebuah program perangkat lunak. Hasil tahap ini adalah program komputer sesuai dengan desain yang telah dibuat pada tahap desain.

4) Pengujian

Pada tahap ini, pengujian prototipe telah dibuat oleh penulis. Untuk membuktikan bahwa prototipe yang dibuat berlaku. Dalam penelitian ini, penulis tidak membuat program lolos pada tahap coding karena penelitian yang dilakukan oleh penulis terbatas pada analisis dan desain sistem informasi, sedangkan pada tahap pengujian penulis melakukan pengujian prototipe yang telah dibangun.

5) Pengujian prototipe

Pada tahap ini, pengujian prototipe telah dibuat oleh penulis. Untuk membuktikan prototype

6) Evaluasi Prototype Hasil Pengujian

Pada tahap ini penulis mengevaluasi hasil pengujian yang dilakukan oleh penulis, di mana penulis meneliti dan memberikan penilaian terhadap prototipe sistem yang akan dibangun. 


\section{HASIL DAN PEMBAHASAN}

\section{Analisis Dan Desain}

\section{Analisis Sistem Current}

Sistem yang saat ini digunakan di PT. Rizki Kartika Ariana Purwakarta adalah ketika seorang pelanggan datang, maka perusahaan pasti akan bertanya apa kebutuhan pelanggan berada. Jika pelanggan ingin membeli kayu lapis atau kayu lapis bahan baku, perusahaan secara manual akan memeriksa apakah kayu lapis atau kayu lapis bahan baku yang diinginkan oleh pelanggan tersedia. Dalam hal ini pemeriksaan manual tentu membuat menunggu pelanggan. Jika kayu lapis atau kayu lapis bahan baku yang tersedia, perusahaan akan mengambil kayu lapis atau kayu lapis bahan baku dan memberitahu harga kepada pelanggan. Setelah itu pelanggan akan membayar total biaya yang harus dibayar, dan jika pelanggan menginginkan bukti transaksi atau penjualan catatan, maka perusahaan akan membuat catatan penjualan bagi pelanggan. Jika kayu lapis atau kayu lapis bahan baku tidak ditemukan atau digunakan.

Dari analisis sistem yang sedang berjalan, ditemukan kelemahan dalam melaksanakan kegiatan di perusahaan PT. Rizki Kartika Ariana Purwakarta yaitu:

1) Sistem penjualan konvensional diterapkan perusahaan PT. Rizki Kartika Ariana Purwakarta tentunya membutuhkan pelanggan untuk datang langsung ke perusahaan dan ini menghambat pengembangan bisnis karena kesulitan dalam menambahkan pelanggan baru.

2) Tidak tersedianya informasi yang up-to-date baik dari segi stok dan harga, sehingga menjadi masalah dalam membuat penjualan.

3) Tidak tersedianya laporan yang akurat tentu menjadi kendala bagi perusahaan dalam memenuhi kebutuhan informasi yang diinginkan.

4) Mencari dokumen dalam bentuk hard copy sehingga dibutuhkan waktu yang lama untuk mencari dokumen.

\section{Solusi masalah}

Berdasarkan beberapa kelemahan yang terdapat dalam sistem yang sedang berjalan di PT. Rizki Kartika Ariana Purwakarta, penulis memberikan solusi untuk masalah membangun sistem informasi penjualan berbasis web yang bisa dimanfaatkan sebagai fasilitas penjualan untuk kayu lapis atau kayu lapis bahan baku secara online yang mampu memperluas pangsa pasar dan dapat menghasilkan informasi yang dibutuhkan lebih cepat dan akurat.

\section{Analisis Pesyaratan sistem}

1) Analisis Kebutuhan Fungsional

Analisis kebutuhan fungsional digunakan pada PT. Rizki Kartika Ariana Purwakarta adalah sebagai berikut:

a. Sistem yang digunakan terdiri dari pengolahan data pelanggan, pesanan, kategori, bahan, kayu lapis, lokasi pengiriman, ukuran, dan profil.

b. Pengguna yang berinteraksi pada sistem pengunjung, pelanggan dan admin.

c. Laporan yang dihasilkan laporan pesanan, laporan materialfourite, dan laporan plywood favorit.

d. Pengunjung berinteraksi dengan sistem hanya untuk melihat informasi.

e. Pelanggan berinteraksi dengan sistem untuk menempatkan pesanan dan melihat informasi. 
f. Admin berinteraksi dengan sistem untuk mengkonfirmasi pelanggan yang memesan.

2) Analisis Kebutuhan Non-Fungsional

Analisis kebutuhan non-fungsional digunakan pada PT. Rizki Kartika Ariana

Purwakarta adalah sebagai berikut:

a. bahasa pemrograman yang digunakan adalah PHP dan DBMSMySQL.

b. Sistem ini dapat diakses 24 jam online.

c. Sistem ini dilengkapi dengan pencarian berdasarkan kata kunci.

d. Sistem ini dilengkapi dengan username dan password.

3) Analisis Sistem Proses

Berdasarkan hasil analisis sistem yang sedang berjalan, untuk mengatasi masalah yang ditemukan, diharapkan bahwa sistem yang dikembangkan dapat memenuhi beberapa persyaratan sistem, termasuk:

a. Sistem akan memberikan halaman masukan untuk memesan kayu lapis atau kayu lapis bahan baku.

b. Sistem ini akan memberikan informasi tentang kayu lapis atau kayu lapis bahan baku termasuk nama-nama plywood atau bahan baku kayu lapis, harga, dan saham.

c. Sistem ini akan memberikan kayu lapis basis data pemesanan atau kayu lapis bahan baku diproses.

Dalam analisis memesan kayu lapis atau kayu lapis bahan baku di PT. Rizki Kartika Ariana Purwakarta online dapat dirancang oleh penulis menggunakan menggunakan diagram kasus yang menggambarkan batas-batas sistem yang dimodelkan. Selain itu juga menggambarkan sistem yang akan dirancang dengan sistem yang sedang berjalan.

\section{KESIMPULAN DAN SARAN}

\section{Kesimpulan}

Dari merancang penjualan berbasis web dan memesan sistem di PT. Rizki Kartika Ariana Purwakarta, maka beberapa kesimpulan yang bisa ditarik termasuk:

1) Melalui penjualan berbasis web, diharapkan kinerja dan pemasaran perusahaan jangkauan kepada konsumen dapat diperluas dan ditingkatkan

2) sistem pemesanan berbasis web memudahkan konsumen untuk mendapatkan informasi yang lebih lengkap dan cepat, mulai dari metode pembayaran untuk transaksi pembayaran.

\section{Saran}

Saran yang penulis dapat memberikan untuk pengembangan penjualan berbasis web dan sistem pemesanan yang lebih baik adalah:

1) Sistem yang diusulkan berfokus pada pembahasan pemesanan barang saja dan tidak memperhatikan aspek multimedia. Oleh karena itu penulis menyarankan bahwa aplikasi web ini dapat dikembangkan lebih sempurna oleh peneliti berikutnya.

2) Perusahaan harus mampu membuat harga kayu lapis atau kayu lapis bahan baku secara tanggal dan bulanan sehingga konsumen atau pelanggan dapat membedakan Informasi harga setiap bulan.

\section{DAFTAR RUJUKAN}

Al Fatta, Hanif. 2007. Analisis \& Perncangan Sistem Informasi. Yogyakarta: Andi Yogyakarta. Anhar, 2010. PANDUAN Mengenai PHP Dan MySQL. Jakarta: andi. 
Darma ;, Jarot, S \& Shenia, A. 2009. Buku Pintar Menguasai Internet. Jakarta: Mediakita. Fauzi, Ahmad. 2008. Pengantar Teknologi Informasi. Bandung: Graha Ilmu.

Hermawan, Dadang; \& Ahmadi, Candra. 2013. E-Bisnis dan E-Commerce. Yogyakarta: Andi.

Haryanto, Karim; \& Hendarti, Henny. 2009. Nasional Informatika. UPN Veteran. Yogyakarta: Binus University.

Hariyanto, Bambang. 2004. Sistem Manajemen Basis Data permodelan, Perancangan, Dan terapannya. Bandung: Informatika. Kadir, Abdul. 2003. Dasar pemograman Web Dinamis MENGGUNAKAN PHP. Yogyakarta: andi.

Loudon. Jenep; \& Loudon CH Kennet. 2007. Sistem Informasi Manajemen. Jakarta: Salemba Empat. Madcom. 2011. Adobe Dreamweaver CS6 Mencari Google Artikel PHP \& MySQL, Yogyakarta: Andi

Mcleod, Jr Raymond; \& P. Schell, George. 2007. Manajemen Informasi Sistem edisi Kesepuluh. New Jersey nited Serikat amerika: orang Prentice Hall

Indra, Dedy. 2013. Perancangan E-Commerce PADA Dwitama Komputer. Tesis TIDAK terpublikasi. Jambi: Stikom Dinamika Bangsa.

Nurcahyono, Fendi. 2012. Sentra Penelitian Teknik Dan Edukasi, Volume 4, Nomor 3.

Nugroho. 2010. Rekayasa Perangkat Lunak Berbasis Objek Mencari Google Artikel Metode USDD. Yogyakarta: Benny Hermawan. Nugroho, Bunafit. 2008. Aplikasi pemograman Web Dinamis Mencari Google Artikel PHP Dan MySQL. Yogyakarta: Andi.

O' Brain, James d \& Marakas, George. 2011. Sistem Informasi Manajemen. Amerika: M. Graw.Hill / Jika winn.

Indra, Dedy. 2013. Perancangan E-Commerce PADA Dwitama Komputer. Tesis TIDAK terpublikasi. Jambi: Stikom Dinamika Bangsa.

Rosa, A. \& Shalahuddin, M. 2013. Rekayasa Perangkat Lunak. Bandung: Informatika.

Raharjo, Budi. 2011. Belajar Otodidak MEMBUAT Data Base MENGGUNAKAN MySQL. Bandung: Informatika. Rudyanto, M. 2011. Aplikasi web DENGAN PHP Dan MySQL. Yogyakarta: Andi

Saputro, Uji. 2008. Teknologi Informasi dan Komunikasi: Bumi Aksara ..

Sidik, Betha. 2005. pemograman Web Mencari Google Artikel HTML. Edisi Kedua. Bandung: Informatika. Yulianto, Lies; \& Iswanto, Yogi. 2014. Sentra Penelitian Teknik Dan Edukasi, Volume 11 No 2

Wangdra, Tonny; \& Hapzi, Ali. MM.2010. Sistem Informasi Bisnis SI-BIS. Babuose Media(Http://www.biopolish.com/mengenal-plywood-atau-tripleks-496/). Diakses PADA Tanggal 15 Oktober 2019. (http://id.techinasia.com/toko-online-popular-diindonesia). Diakses PADA Tanggal 15 Oktober 2019.

Almilia Dan Irmaya Briliantien "Faktor - Faktor Yang Mempengaruhi KINERJA Sistem

Informasi Akuntansi PADA Bank Umum Pemerintah di Wilayah Surabaya dan Sidoarjo"Artikel Penelitian Sistem Informasi Akuntansi 2007. 